\title{
Zingiber officinale acts as a nutraceutical agent against liver fibrosis
}

\author{
Tarek K Motawi ${ }^{1}$, Manal A Hamed ${ }^{2 *}$, Manal H Shabana ${ }^{3}$, Reem M Hashem ${ }^{4}$ and Asmaa F Aboul Naser ${ }^{2}$
}

\begin{abstract}
Background/objective: Zingiber officinale Roscoe (ginger) (Zingiberaceae) has been cultivated for thousands of years both as a spice and for medicinal purposes. Ginger rhizomes successive extracts (petroleum ether, chloroform and ethanol) were examined against liver fibrosis induced by carbon tetrachloride in rats.

Results: The evaluation was done through measuring antioxidant parameters; glutathione (GSH), total superoxide dismutase (SOD) and malondialdehyde (MDA). Liver marker enzymes; succinate and lactate dehydrogenases (SDH and LDH), glucose-6-phosphatase (G-6-Pase), acid phosphatase (AP), 5'- nucleotidase (5'NT) and liver function enzymes; aspartate and alanine aminotransferases (AST and ALT) as well as cholestatic markers; alkaline phosphatase (ALP), gamma glutamyl transferase (GGT), total bilirubin were estimated. Liver histopathological analysis and collagen content were also evaluated. Treatments with the selected extracts significantly increased GSH, SOD, SDH, LDH, G-6-Pase, AP and 5'NT. However, MDA, AST, ALT ALP, GGT and total bilirubin were significantly decreased.
\end{abstract}

Conclusions: Extracts of ginger, particularly the ethanol one resulted in an attractive candidate for the treatment of liver fibrosis induced by $\mathrm{CCl}_{4}$. Further studies are required in order to identify the molecules responsible of the pharmacological activity.

Keywords: Zingiber officinale, liver fibrosis, enzymes, antioxidants, histology

\section{Background}

Liver plays a pivotal role in regulating various physiological processes in the body such as metabolism, secretion and storage. It has great capacity to detoxicate toxic substances and synthesize useful principles. Therefore, damage on the liver inflicted by hepatotoxic agents is of grave consequences [1].

Evidences developed over the last years have suggested that various forms of liver injuries may be caused by free radical formation and subsequent oxidative stress. It is believed that reactive oxygen species (ROS), such as hydroxyl radical, superoxide radical anion and nitric oxide may injure cell membranes through lipid peroxidation [2]. Apparently ROS modify or damage biomolecules, i.e., proteins, lipids, carbohydrates and DNA [3]. Oxidative stress lead to the formation of glycoxidation products, including advanced glycation end products

\footnotetext{
* Correspondence: manal_hamed@yahoo.com

${ }^{2}$ Therapeutic Chemistry Department, National Research Center, El-Tahrir St., Dokki, Cairo, 12311, Egypt

Full list of author information is available at the end of the article
}

(AGEs - among them $N \varepsilon$-(carboxymethyl) lysine (CML) is best known), and advanced oxidation protein products (AOPPs). The receptor for advanced glycation end products (RAGE) is a signal transduction receptor that binds both AGEs and AOPPs. RAGE is expressed by hepatic stellate cells and myofibroblasts, which are the relevant cells for fibrogenesis of chronic liver disease. Both AGEs and AOPPs trigger the inflammatory response via interaction with RAGE and by causing activation of nuclear factor NF- $\kappa$ B [4]. Since advanced oxidation protein products are not only markers of oxidative stress but also act as inflammatory mediators [5], the knowledge of AOPPs pathophysiology in chronic liver disease could provide valuable information with respect to the relationship between oxidative stress and the inflammatory response related to liver fibrosis [6].

Carbon tetrachloride $\left(\mathrm{CCl}_{4}\right)$, as a xenobiotic, caused oxidative stress and may injuries hepatic cells [7]. Many studies have established the fact that $\mathrm{CCl}_{4}$ is metabolized in the liver into a highly reactive substance, 
trichloromethyl, which initiate free radicals that mediate lipid peroxidation [8].

For this reason, anti-oxidation is an extremely significant activity which can be used as a preventive agent against diseases [9]. In spite of tremendous advances in modern medicine, there are no effective drugs available to improve liver function, offer protection or help to regenerate hepatic cells [1]. In absence of reliable liverprotective drugs, therefore, attention is focused on natural antioxidants. Natural antioxidants are polyphenol compounds which are found in all plants [10].

Ginger (Zingiber officinale Roscoe; Zingiberaceae) has been used as a spice for over thousand years [11]. Its roots contain polyphenol compounds (6-gingerol and shogaols), which have a high antioxidant activity [12]. In addition, ginger reported as detoxifying agent against alcohol abuse [13] and bromobenzene intoxication [14]. Matsuda et al. [15] and Habib et al. [16] mentioned its antidiabetic, antihyperlipidimic and hepatic anticancer effect.

According to glossary produced by American Diabetics and Association, neutriceutics are substances considered as food or a part of it that offers health or medicinal benefit, including prevention and treatment of diseases [17]. Some of the natural products find their use not as pharmaceuticals (real medicine) but as a novel class of dietary supplements or nutraceuticals that fall well into the concept of functional foods. Ginger has been listed in "Generally Recognized as Safe" (GRAS) document of the US FDA, where a dose of 0.5-1.0 g of ginger powder ingested 2-3 times for periods ranging from 3 months to 2.5 years did not cause any adverse effects [18].

Despite the favorable ethnopharmacological properties of ginger, its protective effect against liver fibrosis has not previously been explored and its role as diminished factor of fibrosis could be a marker of therapeutic benefit. The aim of the present study was to evaluate successive ginger extracts (petroleum ether, chloroform and ethanol) against liver fibrosis induced by $\mathrm{CCl}_{4}$ in rats. The evaluation was done through measuring certain antioxidant parameters, hepatic marker enzymes, liver function indices, cholestatic biomarkers and histological analysis of the liver sections.

\section{Material and methods}

\subsection{Chemicals}

All chemicals in the present study were of analytical grade, product of Sigma (US), Merck (Germany) and BDH (England).

\subsection{Plant collection}

Ginger rhizomes were purchased from local market (Hyper One, $6^{\text {th }}$ October City, Egypt) and identified by
Dr. Manal Shabana, Phytochemistry and Plant Systematic Department, National Research Center, Egypt. Voucher specimen (ZOR-2010) was deposited as a reference at Therapeutic Chemistry Department, NRC. Dried rhizomes were ground in a grinder with $2 \mathrm{~mm}$ diameter mesh and kept in tightly closed container until needed.

\subsection{Plant Extraction}

The dried powdered rhizomes ( $500 \mathrm{~g}$ ) were successively extracted in a Soxhlet apparatus using solvents of increasing polarities: petroleum ether $\left(40-60^{\circ} \mathrm{C}\right)$, chloroform and $95 \%$ ethanol for $72 \mathrm{~h}$ of each solvent [19]. Solvent removal was carried by evaporation under reduced pressure at $40^{\circ} \mathrm{C}$ yielding semisolid residues of $1.3,0.80$ and $2.35 \% \mathrm{w} / \mathrm{w}$, respectively.

\subsection{Phytochemical screening}

All extracts were tested for carbohydrates, sterols, terpenes [20], flavonoids, tannins, oils [21] and alkaloids [22].

\subsection{Animals}

Male Wistar albino rats (100: $120 \mathrm{~g}$ ) were selected for this study. They were obtained from the Animal House, National Research Center, Egypt. All animals were kept in controlled environment of air and temperature with access of water and diet. Anesthetic procedures and handling with animals complied with the ethical guidelines of Medical Ethical Committee of National Research Centre in Egypt (Approval no: 10031).

\subsection{Doses and route of administration}

Administration regimen was twice a week for six consecutive weeks. $\mathrm{CCl}_{4}(0.5 \mathrm{ml} / \mathrm{kg})$ was suspended in olive oil (1:9 v/v) and injected intraperitoneally [23]. Ginger extracts were administrated orally at a dose $200 \mathrm{mg} / \mathrm{kg}$ ) [14]. Silymarin; a reference herbal drug was orally administered at a dose $100 \mathrm{mg} / \mathrm{kg}$ [24].

Normal control group was orally vehicle with $0.5 \mathrm{ml}$ normal physiological saline and intraperitoneally received $0.5 \mathrm{ml}$ olive oil. Control groups treated with ginger extracts were intraperitoneally vehicle with 0.5 $\mathrm{ml}$ olive oil. $\mathrm{CCl}_{4}$ group was orally vehicle with $0.5 \mathrm{ml}$ of normal physiological saline.

\subsection{Experimental groups}

72 male Wistar strain albino rats were used in this study. Animals were divided into 9 groups (8 rats each). Group1 served as normal healthy control rats. Groups 2-4 were normal healthy rats administered with ginger extracts (petroleum ether, chloroform and ethanol). Group 5 injected with $\mathrm{CCl}_{4}$. Groups 6-8 forced at the same time with $\mathrm{CCl}_{4}$ and ginger extracts. Group 9 forced with $\mathrm{CCl}_{4}$ and silymarin drug. 


\subsection{Sample preparations}

Serum sample: Blood collected from each animal by puncture the sublingual vein in clean and dry test tube, left $10 \mathrm{~min}$ to clot and centrifuged at $3000 \mathrm{rpm}\left(4^{\circ} \mathrm{C}\right)$ for serum separation. The separated serum was stored at $-80^{\circ} \mathrm{C}$ for further determinations of liver function enzymes, cholestatic biomarkers and serum protein.

Liver tissue was homogenized in normal physiological saline solution $(0.9 \% \mathrm{NaCl})(1: 9 \mathrm{w} / \mathrm{v})$. The homogenate was centrifuged at $4^{\circ} \mathrm{C}$ for $5 \mathrm{~min}$ at $3000 \mathrm{rpm}$. The supernatant was used for estimation of liver marker enzymes and the antioxidant parameters.

\subsection{Biochemical assays}

\subsubsection{Antioxidant parameters}

Malondialdehyde as a product of polyunsaturated fatty acids oxidation was determined by the method of Buege and Aust [25]. Its concentration was calculated using the extinction coefficient value $1.56 \times 10^{5} \mathrm{M}^{-1} \mathrm{~cm}^{-1}$ and read at $535 \mathrm{~nm}$. Glutathione was assayed by the method of Moron et al. [26] using dithiobis-2-nitrobenzoic acid (DTNB) in PBS. The reaction colour was read at 412 nm. Total superoxide dismutase was estimated by method of Nishikimi et al. [27], where the increase in NADH oxidation was measured at $560 \mathrm{~nm}$ using its molar extinction coefficient $6.22 \times 10^{3} \mathrm{M}^{-1} \mathrm{~cm}^{-1}$.

\subsubsection{Hepatic cell organelles markers}

Succinate dehydrogenase; a marker for mitochondria was estimated by the method of Rice and Shelton [28], where the reduction of flavin adenine dinucleotide was coupled with a reduction of tetrazolium salt as 2-p-iodophenyl-3-p-nitrophenyl-5-phenyl tetrazolium chloride (INT) and the produced formazan of INT was measured colorimetrically at $490 \mathrm{~nm}$. Lactate dehydrogenase; a marker for cytoplasm was estimated by the method of Babson and Babson [29], where the reduction of nucleoside derived amino acids (NAD) was coupled with the reduction of tetrazolium salt and the produced formazan of INT was measured colorimetrically at $503 \mathrm{~nm}$. The three enzymes, G-6-Pase (microsome marker), acid phosphatase (lysosome marker) and 5'- nucleotidase (plasma membrane marker) were measured colorimetrically as inorganic phosphorus released at $660 \mathrm{~nm}$ [30-32], respectively.

\subsubsection{Serum biomarkers for liver function tests and total protein level}

Aspartate and alanine amintransferases were measured by the method of Gella et al. [33], where the transfer of amino group from aspartate or alanine formed oxalacetate or pyruvate, respectively and the developed colour was measured at $520 \mathrm{~nm}$. Total protein was assayed by the method of Bradford [34], where Coomassie Brilliant Blue dye reacted with Bradford reagent and gave a blue complex at $595 \mathrm{~nm}$.

\subsubsection{Cholestatic indices}

Alkaline phosphatase catalyzed in alkaline medium the transfer of phosphate group from 4-nitrophosphatase to 2-amino-2-methyl-1-propanol (AMP) and librated 4nitrophenol. The developed colour was measured at 510 $\mathrm{nm}$ [35]. GGT was estimated by the method of Szasz [36], where GGT enzyme reacted with L- $\gamma$ - glutamyl-3carboxy-p-nitroanilide and glycyl-glycine to give L- $\gamma$ glutamyl-glycyl-glycine and 5-amino-2-nitrobenzoate. The decrease in absorbance was read at $450 \mathrm{~nm}$ at 1 min intervals for 3 minutes. Total bilirubin was measured by the method of Doumas et al. [37], where it reacted with diazotized sulfanilic acid in the presence of caffeine with final azo-pigment product. The developed colour was read at $546 \mathrm{~nm}$.

\subsection{Histopathological study}

Liver slices were fixed in $10 \%$ paraformaldehyde and embedded in paraffin wax blocks. Sections of $5 \mu \mathrm{m}$ thick were stained with hematoxylin \& eosin (H\&E) and Masson's trichrome, then examined under light microscope for determination of pathological changes [38]. Collagen content was determined in Masson's trichrome sections and expressed as collagen volume, where volume of collagen $(\%)=$ number of points failing on 10 successive fields/number of points in the reticule $\left(1 \mathrm{~cm}^{2}\right.$ eye piece reticule) $\times 100$ [39] .

\subsection{Statistical analysis and calculations}

All data were expressed as mean \pm SD of eight rats in each group. Statistical analysis was carried out by oneway analysis of variance (ANOVA), Costat Software Computer Program. Significance difference between groups was at $\mathrm{p}<0.05$.

$\%$ change $=$ control mean - treated mean $/$ control mean $\times 100$.

$\%$ improvement $=$ treated mean - injured mean $/$ control mean $\times 100$.

\section{Results}

\subsection{Phytochemical screening}

Phytochemical screening of ginger ethanolic extract revealed abundant presence of flavonoids and tannins. High concentration of carbohydrates and moderate concentration of alkaloids were recorded. Chloroformic extract contained moderate concentrations of sterols and terpenes, while petroleum ether one contained moderate lipids content (Table 1).

\subsection{Extracts safety}

Normal healthy rats administrated with ethanol and chloroform extracts recorded insignificant changes in all parameters under investigation revealing extracts safety. Petroleum ether extract showed significant changes in 
Table 1 Phytochemical screening of successive ginger extracts

\begin{tabular}{cccc}
\hline Constituents & Petroleum ether & Chloroform & Ethanol \\
\hline Carbohydrate & - & - & +++ \\
Flavonoids & - & - & ++++ \\
Tannins & - & - & ++++ \\
Sterols & - & ++ & - \\
Terpenes & - & ++ & - \\
Alkaloids & - & - & - \\
Oils & ++ & - & -
\end{tabular}

- = Not present

$\bullet+=$ Present in low concentration

- $++=$ Present in moderately high concentration

$\bullet+++=$ Present in very high concentration.

$\bullet++++=$ Abundantly present.

AP, AST, ALT, liver and body weight (Additional file 1 Tables S1-S5).

\subsection{Effect of Zingiber officinale on hepatic antioxidant} levels

$\mathrm{CCl}_{4}$ group recorded significant decrease in glutathione $(63.63 \%)$ and total SOD (49.73\%) levels, while malondialdehyde showed significant increase by $38.00 \%$ (Table 2 ). Treatment with ethanol extract improved MDA and SOD levels by 60.56 and $10.70 \%$, respectively. Glutathione enhanced after treatment with chloroform and ethanol extracts by 32.70 and $27.97 \%$. Treatment with silymarin recorded improvement in GSH, MDA and SOD by $40.08,35.21$ and $3.84 \%$, respectively.

\subsection{Efficiency of Zingiber officinale on hepatic marker enzymes}

Fibrotic liver induced by $\mathrm{CCl}_{4}$ recorded significant decrease in SDH, LDH, G-6-Pase, AP and 5'NT by $22.65,32.50,24.40,35.13$ and $47.22 \%$, respectively (Table 3 ). Treatment with ginger extracts recorded improvement in all marker enzymes, whereas ethanolic extract showed higher improvement percentages than the other ones. It recorded enhancement by $13.85,9.42$, 20.60 and $25.41 \%$ for SDH, G-6-Pase, AP and 5'NT, respectively. Contradictory, $\mathrm{LDH}$ enzyme recorded higher improvement level after treatment with petroleum ether extract (29.9\%) (Table 3). Treatment with silymarin improved SDH, LDH, G-6-Pase, AP and 5'NT by $6.39,23.76,8.69,8.18$ and $17.77 \%$, respectively.

\subsection{Potency of Zingiber officinale in improving liver function enzymes and serum protein}

$\mathrm{CCl}_{4}$ group, showed significant increase in AST and ALT levels by 88.34 and $43.52 \%$, respectively (Table 4 ). However, serum total protein was insignificantly increased by $8.93,6.97$ and $3.91 \%$ after treatment with ethanol, chloroform and petroleum ether extracts, respectively. The observed changes in liver function enzymes showed that ethanol extract recorded the most improvement percentages than the other extracts. AST and ALT were ameliorated by 31.11 and $21.26 \%$, while serum protein was improved by $15.19,13.24$ and $12.39 \%$ for the three extracts, respectively. Silymarin enhanced AST, ALT and total protein levels by 36.66, 22.84 and $12.39 \%$, respectively.

\subsection{Efficacy of Zingiber officinale on serum cholestatic markers}

As compared to normal healthy rats, $\mathrm{CCl}_{4}$ group recorded significant increase in GGT, ALP and total bilirubin by $55.70,46.61$ and $157.14 \%$, respectively (Table 5). Improvement in serum cholestatic biomarkers after treatment revealed that all extracts shared in improvement by high percentages. Treatment with ethanol extract recorded the highest improving percent in GGT and total bilirubin (53.99 and 154.76\%). ALP enhanced by $33.81,44.74$ and $41.29 \%$ after treatment with ethanol, chloroform and petroleum ether extracts, respectively. GGT, ALP and total bilirubin recorded improvement percentages reached to $43.85,33.81$ and $152.38 \%$ after silymarin treatment.

Table 2 Effect of Zingiber officinale extracts on hepatic antioxidant levels in $\mathrm{CCl}_{4}$ treated rats

\begin{tabular}{|c|c|c|c|c|c|c|}
\hline Parameters & Control & $\mathrm{CCl}_{4}$ group & $\begin{array}{c}\mathrm{CCl}_{4} \text { treated } \\
\text { with } \\
\text { ethanol extract }\end{array}$ & $\begin{array}{c}\mathrm{CCl}_{4} \text { treated with } \\
\text { chloroform } \\
\text { extract }\end{array}$ & $\begin{array}{c}\mathrm{CCl}_{4} \text { treated with } \\
\text { petroleum } \\
\text { ether extract }\end{array}$ & $\begin{array}{l}\mathrm{CCl}_{4} \text { treated with } \\
\text { silymarin }\end{array}$ \\
\hline GSH & $\begin{array}{c}783.81 \pm \\
124.87 \\
\text { (a) }\end{array}$ & $\begin{array}{c}285.00 \pm \\
59.42 \\
\text { (c) }\end{array}$ & $\begin{array}{c}504.26 \pm 59.49 \\
\text { (b) }\end{array}$ & $\begin{array}{c}541.35 \pm 85.34 \\
\text { (b) }\end{array}$ & $\begin{array}{c}523.58 \pm 66.47 \\
\text { (b) }\end{array}$ & $\begin{array}{c}599.16 \pm 128.39 \\
\text { (b) }\end{array}$ \\
\hline MDA & $\begin{array}{c}0.71 \pm 0.12 \\
\text { (b) }\end{array}$ & $\begin{array}{c}0.98 \pm 0.25 \\
\text { (a) }\end{array}$ & $\begin{array}{c}0.77 \pm 0.04 \\
\text { (b) }\end{array}$ & $\begin{array}{c}0.76 \pm 0.12 \\
\text { (b) }\end{array}$ & $\begin{array}{c}0.78 \pm 0.14 \\
\text { (b) }\end{array}$ & $\begin{array}{c}0.73 \pm 0.03 \\
\text { (b) }\end{array}$ \\
\hline Total SOD & $\begin{array}{c}16.91 \pm 2.63 \\
\text { (a) }\end{array}$ & $\begin{array}{c}8.50 \pm 1.76 \\
\text { (b) }\end{array}$ & $\begin{array}{c}10.31 \pm 2.53 \\
\text { (b) }\end{array}$ & $\begin{array}{c}9.76 \pm 2.45 \\
(b)\end{array}$ & $\begin{array}{c}9.41 \pm 1.97 \\
\text { (b) }\end{array}$ & $\begin{array}{c}9.15 \pm 2.70 \\
\text { (b) }\end{array}$ \\
\hline
\end{tabular}

- Data are means \pm SD of eight rats in each group.

- Data are expressed as $\mu \mathrm{g} / \mathrm{mg}$ protein for GSH and $\mu \mathrm{mol} / \mathrm{mg}$ protein for MDA and total SOD.

- Unshared letters between groups are the significance values at $p<0.0001$

- Statistical analysis is carried out using one way analysis of variance (ANOVA), CoStat Computer Program. 
Table 3 Effect of Zingiber officinale extracts on hepatic marker enzymes in $\mathrm{CCl}_{4}$ treated rats

\begin{tabular}{|c|c|c|c|c|c|c|}
\hline Parameters & Control & $\mathrm{CCl}_{4}$ group & $\begin{array}{l}\mathrm{CCl}_{4} \text { treated with } \\
\text { ethanol extract } \\
\text { ethanol extract }\end{array}$ & $\begin{array}{l}\mathrm{CCl}_{4} \text { treated with } \\
\text { chloroform extract } \\
\text { chloroform extract }\end{array}$ & $\begin{array}{c}\mathrm{CCl}_{4} \text { treated with } \\
\text { petroleum ether } \\
\text { extract }\end{array}$ & $\begin{array}{l}\mathrm{CCl}_{4} \text { treated with } \\
\text { silymarin }\end{array}$ \\
\hline $\mathrm{SDH}$ & $\begin{array}{c}108.86 \pm 24.2 \\
\text { (a) }\end{array}$ & $\begin{array}{c}84.2 \pm 24.2 \\
(\mathrm{~b})\end{array}$ & $\begin{array}{c}99.28 \pm 10.05 \\
(a b)\end{array}$ & $\begin{array}{c}93.79 \pm 6.79 \\
(a b)\end{array}$ & $\begin{array}{c}96.16 \pm 23.51 \\
(a b) \\
\end{array}$ & $\begin{array}{c}91.16 \pm 8.29 \\
(a b)\end{array}$ \\
\hline $\mathrm{LDH}$ & $\begin{array}{c}143.86 \pm 18.12 \\
\text { (a) }\end{array}$ & $\begin{array}{c}97.01 \pm 41.09 \\
(\mathrm{c})\end{array}$ & $\begin{array}{c}124.04 \pm 27.63 \\
(\mathrm{abc})\end{array}$ & $\begin{array}{c}100.83 \pm 12.93 \\
\text { (bc) }\end{array}$ & $\begin{array}{c}140.06 \pm 2.44 \\
\text { (a) }\end{array}$ & $\begin{array}{c}131.2 \pm 35.16 \\
(a b)\end{array}$ \\
\hline G-6-Pase & $\begin{array}{c}43.48 \pm 4.83 \\
\text { (a) }\end{array}$ & $\begin{array}{c}32.87 \pm 2.24 \\
\text { (b) }\end{array}$ & $\begin{array}{c}36.97 \pm 10.31 \\
(a b)\end{array}$ & $\begin{array}{c}34.07 \pm 7.9 \\
\text { (b) }\end{array}$ & $\begin{array}{c}36.55 \pm 2.39 \\
(a b)\end{array}$ & $\begin{array}{c}36.65 \pm 6.33 \\
(a b)\end{array}$ \\
\hline $\mathrm{AP}$ & $\begin{array}{c}63.53 \pm 6.73 \\
\text { (a) }\end{array}$ & $\begin{array}{l}41.21 \pm 2.55 \\
\text { (d) }\end{array}$ & $\begin{array}{c}54.3 \pm 3.01 \\
\text { (b) }\end{array}$ & $\begin{array}{c}48.25 \pm 3.14 \\
\text { (c) }\end{array}$ & $\begin{array}{c}48.35 \pm 4.79 \\
\text { (c) }\end{array}$ & $\begin{array}{c}46.41 \pm 3.19 \\
\text { (c) }\end{array}$ \\
\hline $5^{\prime} \mathrm{NT}$ & $\begin{array}{c}304.25 \pm 58.81 \\
\text { (a) }\end{array}$ & $\begin{array}{c}160.83 \pm \\
29.38 \\
\text { (d) }\end{array}$ & $\begin{array}{c}238.17 \pm 5.79 \\
\text { (b) }\end{array}$ & $\begin{array}{c}215.63 \pm 21.42 \\
\text { (bc) }\end{array}$ & $\begin{array}{c}192.18 \pm 14.9 \\
(\mathrm{~cd})\end{array}$ & $\begin{array}{c}214.9 \pm 47.4 \\
(\mathrm{bc})\end{array}$ \\
\hline
\end{tabular}

- Data are means \pm SD of eight rats in each group.

- Data are expressed as $\mu \mathrm{mole} / \mathrm{min} / \mathrm{mg}$ protein.

- Unshared letters between groups are the significance values at $p<0.0001$.

- Statistical analysis is carried out using one way analysis of variance (ANOVA), CoStat Computer Program.

3.7. Potency of Zingiber officinale in improving liver and relative body weights

$\mathrm{CCl}_{4}$ intoxicated rats showed significant increase in liver weight $(\mathrm{LW})$ and its ratio over body weight (LW/BW) by 21.21 and $69.39 \%$, respectively. However body weight (BW) recorded significant decrease by $28.37 \%$ (Table 6 ). Regarding to the recorded changes in LW, BW and their ratios, ethanol extract showed improvement by 17.92, 12.88 and $39.89 \%$, respectively. Treatment with petroleum ether extract showed enhancement by 14.80 , 10.66 and $34.42 \%$, while chloroform extract recorded enhancement values by 7.07, 3.92 and 34.69\% (Table 6). Silymarin treatment improved LW, BW and their ratio by $0.16,25.55$ and $43.16 \%$, respectively.

\subsection{Effect of Zingiber officinale on collagen content in} $\mathrm{CCl}_{4}$ treated liver

Normal healthy liver of control and control treated with ethanol and chloroform extracts of ginger recorded 5\% collagen deposition. Normal liver treated with petroleum ether extract exerted $10 \%$ collagen content. $\mathrm{CCl}_{4}$ injured liver revealed $70 \%$ collagen deposition. Treatment with ethanol, chloroform, petroleum ether extracts and silymarin recorded decrease in collagen content by 85.71 , 64.28, 28.57 and 78.57\%, respectively (Figure 1).

\subsection{Effect of Zingber officinale on liver morphology}

$\mathrm{CCl}_{4}$ induced changes in liver morphology as compared with normal healthy one (Figure 2-a). Liver colour had changed from normal reddish brown to more or less light brown; a stage of steatosis. The liver enlarges in size and lost it's smoothly surface. Scattered patches of inflammations and pale yellowish fibrotic areas had been seen along with long fibrotic girdle surrounded the outer liver margin (Figure 2-b). Treatment with ethanol extract had returned the liver to it's smoothly appearance, normalized its colour and size and diminished the fibrotic spots to be minimal (Figure 2-c). Chloroform extract of ginger improved the morphological structure of the liver, while a fibrotic area was seen in the hepatic

Table 4 Effect of Zingiber officinale extracts on liver function enzymes and total protein level in serum of $\mathrm{CCl}_{4}$ treated rats

\begin{tabular}{|c|c|c|c|c|c|c|}
\hline Parameters & Control & $\mathrm{CCl}_{4}$ group & $\begin{array}{l}\mathrm{CCl}_{4} \text { treated } \\
\text { with } \\
\text { ethanol extract }\end{array}$ & $\begin{array}{c}\mathrm{CCl}_{4} \text { treated with chloroform } \\
\text { extract } \\
\text { chloroform extract }\end{array}$ & $\begin{array}{l}\mathrm{CCl}_{4} \text { treated with } \\
\text { petroleum ether } \\
\text { extract }\end{array}$ & $\begin{array}{l}\mathrm{CCl}_{4} \text { treated with } \\
\text { silymarin }\end{array}$ \\
\hline AST & $\begin{array}{c}16.39 \pm 1.67 \\
\text { (c) }\end{array}$ & $\begin{array}{c}30.87 \pm 3.35 \\
\text { (a) }\end{array}$ & $\begin{array}{l}25.44 \pm 2.00 \\
\text { (b) }\end{array}$ & $\begin{array}{c}27.22 \pm 2.23 \\
(b)\end{array}$ & $\begin{array}{c}27.72 \pm 2.82 \\
\text { (b) }\end{array}$ & $\begin{array}{c}24.86 \pm 3.37 \\
\text { (b) }\end{array}$ \\
\hline ALT & $\begin{array}{c}33.57 \pm 4.07 \\
\text { (c) }\end{array}$ & $\begin{array}{c}48.31 \pm 6.20 \\
\text { (a) }\end{array}$ & $\begin{array}{c}41.17 \pm 8.38 \\
(a b)\end{array}$ & $\begin{array}{c}42.26 \pm 7.45 \\
(a b)\end{array}$ & $\begin{array}{l}44.82 \pm 2.84 \\
(a b)\end{array}$ & $\begin{array}{l}40.64 \pm 7.72 \\
\text { (bc) }\end{array}$ \\
\hline $\begin{array}{l}\text { Serum } \\
\text { protein }\end{array}$ & $\begin{array}{c}15.33 \pm 4.04 \\
\text { (b) }\end{array}$ & $\begin{array}{c}18.36 \pm 1.35 \\
\text { (a) }\end{array}$ & $\begin{array}{c}16.03 \pm 0.74 \\
(\mathrm{ab})\end{array}$ & $\begin{array}{c}16.33 \pm 0.72 \\
(\mathrm{ab})\end{array}$ & $\begin{array}{c}16.46 \pm 0.30 \\
(\mathrm{ab})\end{array}$ & $\begin{array}{c}16.46 \pm 1.30 \\
(\mathrm{ab})\end{array}$ \\
\hline
\end{tabular}

- Data are means \pm SD of eight rats in each group.

- Liver functions are expressed as Unit/L. Total protein is expressed as $\mathrm{mg} \mathrm{P} / \mathrm{ml}$.

- Unshared letters between groups are the significance values at $\mathrm{p}<0.0001$.

- Statistical analysis is carried out using one way analysis of variance (ANOVA), CoStat Computer Program. 
Table 5 Effect of Zingiber officinale extracts on serum cholestatic markers in $\mathrm{CCl}_{4}$ treated rats

\begin{tabular}{|c|c|c|c|c|c|c|}
\hline Parameters & Control & $\mathrm{CCl}_{4}$ group & $\begin{array}{c}\mathrm{CCl}_{4} \text { treated } \\
\text { with } \\
\text { ethanol extract }\end{array}$ & $\begin{array}{l}\mathrm{CCl}_{4} \text { treated with chloroform } \\
\text { extract }\end{array}$ & $\begin{array}{c}\mathrm{CCl}_{4} \text { treated with } \\
\text { petroleum ether } \\
\text { extract }\end{array}$ & $\begin{array}{l}\mathrm{CCl}_{4} \text { treated with } \\
\text { silymarin }\end{array}$ \\
\hline GGT & $\begin{array}{l}15.78 \pm 1.53 \\
(\mathrm{bc})\end{array}$ & $\begin{array}{c}24.57 \pm 3.48 \\
\text { (a) }\end{array}$ & $\begin{array}{l}16.05 \pm 2.49 \\
\text { (c) }\end{array}$ & $\begin{array}{c}20.25 \pm 6.22 \\
(a b)\end{array}$ & $\begin{array}{l}17.55 \pm 4.57 \\
\quad(\mathrm{bc})\end{array}$ & $\begin{array}{l}17.65 \pm 5.46 \\
\quad(\mathrm{bc})\end{array}$ \\
\hline ALP & $\begin{array}{l}13.90 \pm 1.41 \\
\text { (b) }\end{array}$ & $\begin{array}{c}20.38 \pm 4.37 \\
\text { (a) }\end{array}$ & $\begin{array}{c}15.68 \pm 5.82 \\
(b)\end{array}$ & $\begin{array}{c}14.16 \pm 3.67 \\
(\mathrm{~b})\end{array}$ & $\begin{array}{c}14.64 \pm 2.30 \\
(b)\end{array}$ & $\begin{array}{c}15.68 \pm 2.37 \\
(b)\end{array}$ \\
\hline $\begin{array}{c}\text { Total } \\
\text { bilirubin }\end{array}$ & $0.42 \pm 0.10$ & $\begin{array}{c}1.08 \pm 1.43 \\
\text { (b) }\end{array}$ & $0.43 \pm 0.09$ & $\begin{array}{l}0.45 \pm 0.11 \\
\text { (a) }\end{array}$ & $\begin{array}{l}0.46 \pm 0.11 \\
\text { (a) }\end{array}$ & $\begin{array}{l}0.44 \pm 0.07 \\
\text { (a) }\end{array}$ \\
\hline
\end{tabular}

- Data are means \pm SD of eight rats in each group.

- Data are expressed as Unit/L in GGT, ALP and $\mathrm{mg} / \mathrm{dL}$ in total bilirubin.

- Unshared letters between groups are the significance values at $p<0.001$.

- Statistical analysis is carried out using one way analysis of variance (ANOVA), CoStat Computer Program.

core (Figure 2-d). Petroleum ether extract showed the worst appearance, where large patches as well as many spots of fibrosis were scattered along the liver (Figure 2e). Treatment with silymarin minimally improved the morphological structure of the liver. Many area of fibrosis along the whole liver surface were spread and marked inflammations along the border of the hepatic lobes were observed (Figure 2-f).

\subsection{Liver histopathological analysis}

Fig. (3 a, b) showed liver section of control healthy rats with normal hepatic lobular architecture. The hepatocytes were within normal limits and arranged in thin plates. The hepatocytes were separated by narrow blood sinusoids lined by endothelial cells. Portal tracts extend with no fibrous tissue or lymphocytes deposition. Healthy rats treated with ethanolic extract showed normal hepatic lobular architecture. The hepatocytes were within normal limits and no hydropic or steatosis changes. Portal tracts were normal and no sign of fibrosis (Figure $3 \mathrm{c}, \mathrm{d}$ ). Treatment with chloroform extract of ginger recorded more or less normal hepatocytes architecture (Figure 3 e, f). Petroleum ether extract caused mild hepatocytes aggregation and lymphocytes infiltrations (Figure $3 \mathrm{~g}, \mathrm{~h}$ ).

Injured liver with $\mathrm{CCl}_{4}$ showed portal loss of hepatic lobular architecture. Ballooning of hepatocytes, deformed cord arrangement and disturbed sinusoids were seen. The hepatocytes showed marked degree of hydropic, steatotic changes and massive necrosis. Portal tracts were extended with marked numbers of chronic inflammatory cells and fibrous tissue. There were portoportal and porto-central fibrosis. Fibrosis was markedly presented by $70 \%$ (Figure $4 \mathrm{a}, \mathrm{b}, \mathrm{c}$ ).

Treatments of injured liver with the ethanol extract showed well formed nucleated hepatocytes arranged in cord with obvious sinusoidal arrays. Minimal fat vacuoles and minimal inflammatory lymphocyte infiltrations were observed. Fibrosis reached to 10\% (Figure 4 $\mathrm{d}, \mathrm{e})$. Chloroform extract partly preserved the hepatic normal architecture. Mild degrees of steatosis and hydropic changes were recorded. The hepatocytes were still swollen with narrow sinusoids. Portal tracts were extended with moderate fibrous tissue reached to $25 \%$ (Figures $4 \mathrm{f}, \mathrm{g}$ ). Petroleum ether extract showed narrow sinusoids, ballooning and foamy appearance of heapatocytes. Portal tracts were extended with moderate fibrous tissue reached to $50 \%$ (Figure $4 \mathrm{~h}, \mathrm{i}$ ). $\mathrm{CCl}_{4}$ group treated with silymarin showed well arranged cord of nucleated hepatocytes and sinusoids, while mild fibrotic tissue was still present (15\%) (Figure $4 \mathrm{j}, \mathrm{k}$ ).

\section{Discussion}

Hepatoprotective studies showed that plants have active ingredients that are capable of free radical scavenging in

Table 6 Effect of Zingber officinale extracts on liver and body weights of $\mathrm{CCl}_{4}$ treated rats

\begin{tabular}{|c|c|c|c|c|c|c|}
\hline Parameters & Control & $\mathrm{CCl}_{4}$ group & $\begin{array}{c}\mathrm{CCl}_{4} \text { treated with } \\
\text { ethanol extract }\end{array}$ & $\begin{array}{l}\mathrm{CCl}_{4} \text { treated with } \\
\text { chloroform extract }\end{array}$ & $\begin{array}{c}\mathrm{CCl}_{4} \text { treated with } \\
\text { petroleum ether extract }\end{array}$ & $\mathrm{CCl}_{4}$ treated with silymarin \\
\hline $\begin{array}{l}\text { Liver weight } \\
(\text { LW) }\end{array}$ & $\begin{array}{c}6.08 \pm 0.71 \\
(b)\end{array}$ & $\begin{array}{c}7.37 \pm 0.95 \\
(\mathrm{a})\end{array}$ & $6.28 \pm 0.59$ & $\begin{array}{c}6.94 \pm 1.06 \\
(a b)\end{array}$ & $\begin{array}{c}6.47 \pm 0.93 \\
(a b)\end{array}$ & $\begin{array}{c}7.36 \pm 0.48 \\
\text { (a) }\end{array}$ \\
\hline $\begin{array}{l}\text { Body weight } \\
\text { (BW) }\end{array}$ & $\begin{array}{c}165.66 \pm 12.95 \\
(\mathrm{a})\end{array}$ & $\begin{array}{c}118.66 \pm 4.32 \\
\text { (c) }\end{array}$ & $\begin{array}{c}140.00 \pm 11.83 \\
\text { (b) }\end{array}$ & $\begin{array}{c}125.16 \pm 12.25 \\
(\mathrm{bc})\end{array}$ & $\begin{array}{c}136.33 \pm 26.88 \\
\text { (b) }\end{array}$ & $\begin{array}{c}161.00 \pm 6.38 \\
\text { (a) }\end{array}$ \\
\hline $\begin{array}{c}\% \\
(\mathrm{LW} / \mathrm{BW})\end{array}$ & $\begin{array}{c}3.66 \pm 0.24 \\
\text { (c) }\end{array}$ & $\begin{array}{c}6.20 \pm 0.66 \\
\text { (a) }\end{array}$ & $\begin{array}{c}4.74 \pm 0.96 \\
\text { (b) }\end{array}$ & $\begin{array}{c}4.93 \pm 0.52 \\
\text { (b) }\end{array}$ & $\begin{array}{c}4.94 \pm 0.57 \\
\text { (b) }\end{array}$ & $\begin{array}{c}4.62 \pm 1.02 \\
\text { (b) }\end{array}$ \\
\hline
\end{tabular}

- Data are means \pm SD of eight rats in each group.

- Data are expressed as grams.

- Unshared letters between groups are the significance values at $p<0.0001$

- Statistical analysis is carried out using one way analysis of variance (ANOVA), CoStat Computer Program. 


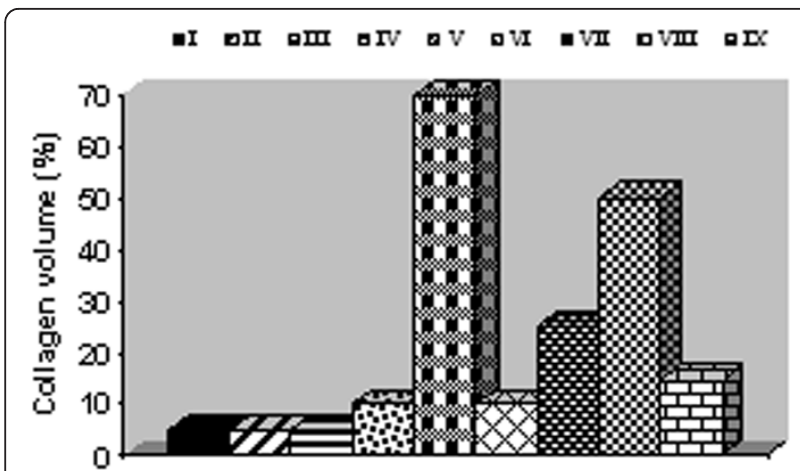

Figure 1 Percentages of collagen deposition in normal and $\mathrm{CCl}_{4}$ treated livers. Normal control (I), control treated with ethanol extract (II), control treated with chloroform extract (III), control treated with petroleum ether extract (IV), $\mathrm{CCl}_{4}$ group $(\mathrm{V}), \mathrm{CCl}_{4}$ treated with ethanol extract $(\mathrm{VI}), \mathrm{CCl}_{4}$ treated with chloroform extract $(\mathrm{VII})$, $\mathrm{CCl}_{4}$ treated with petroleum ether extract $(\mathrm{VIII})$ and $\mathrm{CCl}_{4}$ treated with silymarin (IX).

living systems [10]. Flavonoids, sterols, triterpenes and alkaloids as antioxidative compounds are rich in most plants [40]. In the present study and in accordance with Anosike et al. [41], high content of these compounds was recorded in the ethanol extract of ginger followed

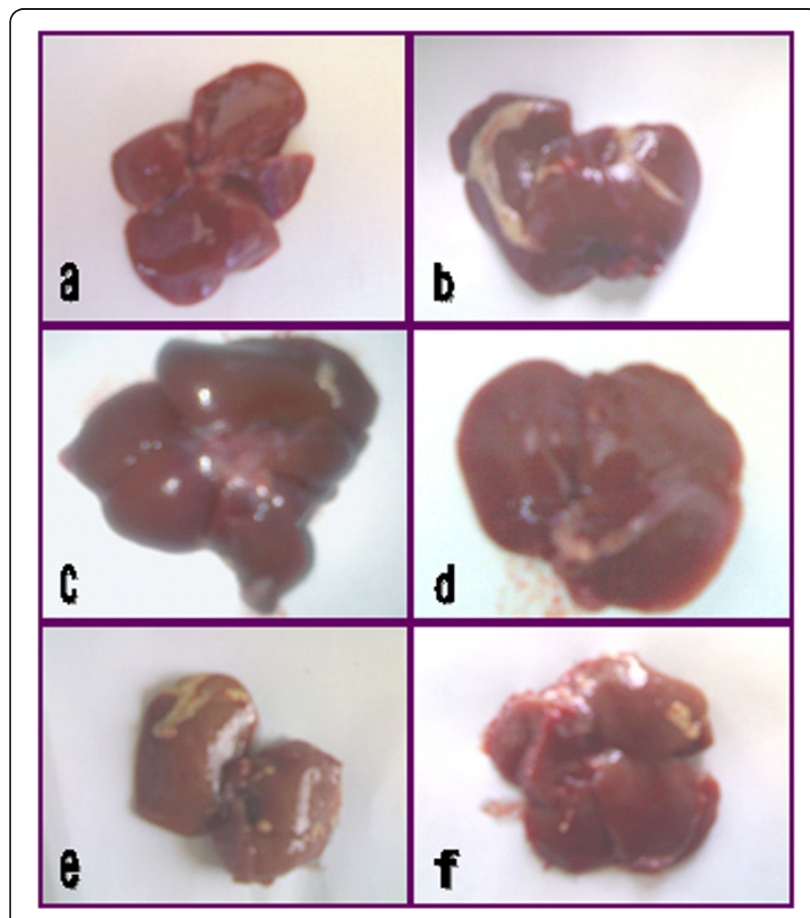

Figure 2 Morphological structure of normal and $\mathrm{CCl}_{4}$ treated livers. Normal control (a), $\mathrm{CCl}_{4}$ injured liver (b), $\mathrm{CCl}_{4}$ treated with ethanol extract (c), $\mathrm{CCl}_{4}$ treated with chloroform extract (d), $\mathrm{CCl}_{4}$ treated with petroleum ether extract (e) and $\mathrm{CCl}_{4}$ treated with silymarin drug $(f)$.

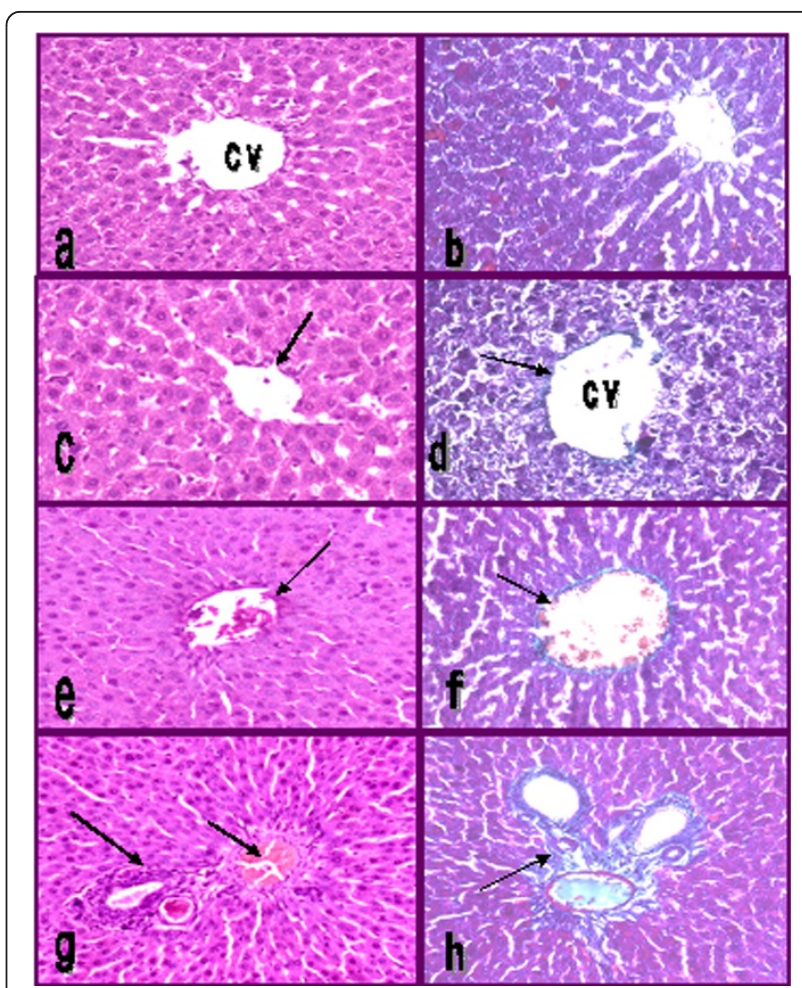

Figure 3 Photomicrograph of H\&E and Masson's trichrom stained liver sections $(100 \times)$ of control $(a, b)$, control treated with ethanol extract $(c, d)$, control treated with chloroform extract $(e, f)$ and control treated with petroleum ether extract $(\mathbf{g}, \mathbf{h})$. Central vein $(\mathrm{CV})$. Arrows indicate collagen deposition.

by chloroform one suggesting their potential role as antioxidative agents.

$\mathrm{CCl}_{4}$ is one of an extensively environmental toxicant. The reactive metabolite trichloromethyl radical $\left(\mathrm{CCl}_{3}{ }^{-}\right)$ has been formed from the metabolic conversion of $\mathrm{CCl}_{4}$ by cytochrome P-450. This reactive metabolite initiates the peroxidation of membrane poly-unsaturated fatty acids (PUFA), generates PUFA radicals, covalently binds to membrane lipids and proteins and generates ROS [42]. Evidence suggests that various enzymatic and nonenzymatic systems have been developed by the cell to attenuate ROS. However, when a condition of oxidative stress establishes, the defense capacities against ROS becomes insufficient. Therefore, ROS affects the antioxidant defense mechanisms, reduces the intracellular concentration of GSH, decreases the activity of SOD and enhances lipid peroxidation [43]. In agreement with these explanations, the observed decrease in SOD was recorded in $\mathrm{CCl}_{4}$ treated rats that may be due to inactivation of the antioxidative enzymes. This may cause an increased accumulation of superoxide radicals, which could further stimulate lipid peroxidation. Decrease in GSH activity might be due to decrease availability of 


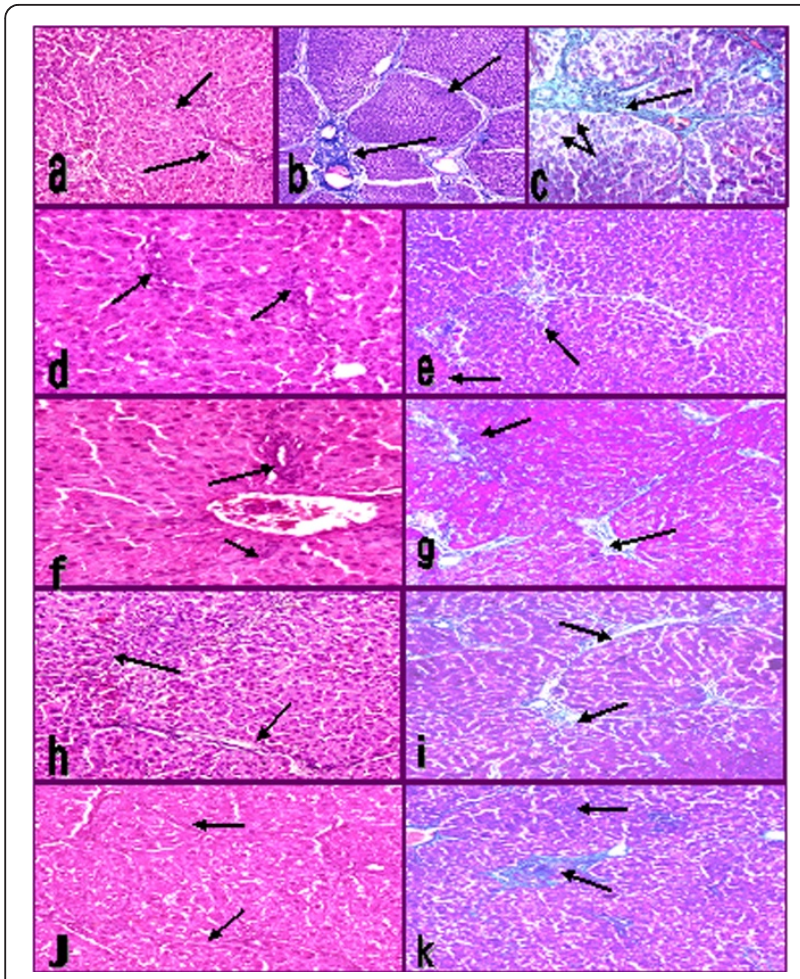

Figure 4 Photomicrograph of H\&E and Masson's trichrom liver sections $(100 \times)$ of $\mathrm{CCl}_{4}$ intoxicated rats $(\mathrm{a}, \mathrm{b}, \mathrm{c}), \mathrm{CCl}_{4}$ treated with ethanol extract $(\mathrm{d}, \mathrm{e})$ and $\mathrm{CCl}_{4}$ treated with chloroform extract $(f, g), \mathrm{CCl}_{4}$ treated with petroleum ether extract $(\mathrm{h}, \mathrm{i})$, $\mathrm{CCl}_{4}$ treated silymarin drug $(\mathbf{j}, \mathbf{k})$. Arrows indicate collagen deposition and lymphocytes infiltrations. Small arrows indicate fat vacuoles deposition and hepatocytes foamy appearance.

GSH resulted during the enhanced lipid peroxidation processes.

Treatment with ginger extracts normalized the antioxidant levels through their rich of flavonoids that have the ability to scavenge free radicals. Silymarin as an antioxidant flavonoid complex derived from the herb milk thistle (Silybum marianum), has the ability to attenuate free radicals elevation, chelates metal ions, inhibits lipid peroxidation and prevents liver glutathione depletion [44].

ALT and AST had been reported to be sensitive indicators of liver injury [45]. Significant elevation of ALT and AST after $\mathrm{CCl}_{4}$ intoxication was in agreement with those reported studies of Opoku et al. [40] and Gowri Shankar et al. [42]. In addition, Romero et al. [46] showed that $\mathrm{CCl}_{4}$ intoxication induced changes in the process of protein synthesis. Hence, increase in total protein content can be deemed as a useful index of the severity of cellular dysfunction in liver diseases as clearly shown in our studies. Stimulation of protein synthesis has been advanced as a contributory self healing mechanism, which accelerates liver regeneration process [47].
Enhancement of cholestatic biomarkers; ALP, GGT and bilirubin were observed in the present study. This was in agreement with Reyes-Gordillo et al. [48] who recorded significant increase in cholestasis biomarker after intoxication of rats with $\mathrm{CCl}_{4}$. Leonard et al. [49] confirmed GGT and bilirubin as indicators of bile duct lesions. Hamed [50] added that GGT alone is a poor indicator of cytotoxicity and suggested the combination of other markers like AST, ALT and LDH for accurate detection and early diagnosis. Opoku et al. [40] and Gowri Shankar et al. [42] explained serum enzymes elevation to the increase in hepatic cell membrane fluidity that led to enzyme release into circulation.

Treatment with ginger extracts attenuated the increased level of serum enzymes and caused a subsequent recovery towards normalization. This give an additional support that ginger extracts are able to condition the hepatocytes, accelerate regeneration of parenchyma cells, protect against membrane fragility and decrease leakage of the enzymes into circulation. Therefore, plant extracts acted by the same mode of action of silymarin [42].

Stressful condition also contribute to the oxidative inactivation of G-6-Pase and 5'- nucleotidase [51]. Inhibition of G-6-Pase and 5'NT activities, in our study, are in agreement with the findings of Opoku et al. [40] and Nkosi et al. [52]. The decreased activities of these marker enzymes during $\mathrm{CC}_{4}$ poisoning confirm microsomal and plasma membrane damage. Though these two enzymes are active in two different metabolic pathways, their functional integrity depends on the chemical composition and physical status of the lipid environment where they are embedded. The decrease in membrane phospholipids due to an increase in phospholipase A2 and $C$ and increased lipid peroxidation could be the reason for the decreased enzyme activities [53]. The observed decrease in $\mathrm{SDH}$ after $\mathrm{CCl}_{4}$ intoxication was in parallel with the finding of Rusu et al. [54]. This decrease in enzyme activity was attributed to the increase in free radicals that affected the inner mitochondrial membrane and intracellular calcium stores led to structural and functional disorganization, over all loss in energy production, irreversible damage, and loss of enzymatic activity [55,56]. Rusu et al. [54] and DeAndrade Belo et al. [57] confirmed the decrease in hepatic $\mathrm{LDH}$ after $\mathrm{CCl}_{4}$ intoxication. Enzyme inhibition was mainly due to increase membrane fluidity as a result of ROS involvement, leads to enzyme leakage into circulation [50]. The decrease in acid phosphatase enzyme activity was in agreement with Kataria and Singh [58] who observed the same alteration in AP after $\mathrm{CCl}_{4}$ induction. Achliya et al. [59] mentioned that the high level of serum AP indicated its 
inhibition in hepatocytes. The same authors explained the repair mechanisms after treatment to the rise of phospholipids that coupled with thymidylate synthetase and thymidine kinase which confirmed liver regeneration.

Regulatory effect of ginger extracts and silymarin on hepatic marker enzymes was documented in our study as free radicals scavengers [60] that could in turn normalize microsomes, lysosomes, mitochondria and plasma membranes permeability and integrity which lead to restore the hepatic enzymes to its normal levels.

The most commonly associated characteristic of liver fibrosis is the increased deposition of collagens. During liver fibrosis, altered collagen synthesis at both mRNA and protein levels is observed, with a dramatic increase in type I collagen along with smaller, but significant, increases in type III collagen. This increase in collagen deposition gave an additional support of the observed increase in liver weight and its ratio over body weight. The excess deposition of extracellular matrix proteins disrupts the normal architecture of the liver, alters its normal function and ultimately leading to pathophysiological damage [61]. The most remarkable pathological characteristics of $\mathrm{CCl}_{4}$-induced hepatotoxicity are massive centrilobular necrosis, ballooning degeneration, cellular infiltration and steatosis [42]. This was in accordance with the present finding of massive deformation of hepatic cells architecture. In ginger and silymarin treated groups, hepatocyte degeneration, necrosis and infiltration of inflammatory cells were all apparently ameliorated. Collagen deposition was markedly reduced. Minimal deposition of fat vacuoles was apparently observed. Silymarin has anti-fibrotic and anti inflammatory effects, inhibit activation of hepatic stellate cells through the expression of transforming growth factor-beta1 and stabilization of mast cells [62]. We compare the anti-fibrogenic effects of silymarin with extracts and the results exhibited that ethanol extract had higher potency in inhibiting collagen deposition and fibrosis severity.

\section{Conclusions}

Ginger has the ability to down regulate free radicals elevation, improve liver and cholestatic biomarkers, ameliorate hepatic marker enzymes, reduce collagen deposition, fibrosis severity and normalize the hepatic cells architecture. Ginger ethanolic extract recorded the most potent effect in improving the selected parameters. The hepatoprotective effect of $Z$. officinale demonstrated in this study may explore its nutraceutical role in human diet. Therefore, further studies are need for its clinical application.

\section{Additional material}

Additional file 1: Effect of successive extracts of Zingiber officinale on certain biochemical parameters in normal control rats. The data provided represent the effect of successive ginger extracts on hepatic antioxidant levels, hepatic marker enzymes, liver function tests, cholestatic indices and liver and body weights in normal healthy rats

\section{Author details}

Biochemistry Department, Faculty of Pharmacy, Cairo University, Kasr El-Aini St., Cairo, 11562, Egypt. ${ }^{2}$ Therapeutic Chemistry Department, National Research Center, El-Tahrir St., Dokki, Cairo, 12311, Egypt. ${ }^{3}$ Phytochemistry and Plant Systematic Department, National Research Center, El-Tahrir St., Dokki, Cairo, 12311, Egypt. ${ }^{4}$ Biochemistry Department, Faculty of Pharmacy, BeniSeuf University, Salah Salem St., Beni-Seuf, 62511, Egypt.

\section{Authors' contributions}

TKM, RMH: Participated in the experimental design and final form of manuscript revision. MAH: Design the experiment, participated in the biochemical analysis and data collections. Performed the statistical analysis, drafted and revised the manuscript. MHS: Plant extractions and phytochemical screening test. AFA: Carried out the experiments and participated in data collections under supervision of MAH. All authors read and approved the final manuscript.

\section{Competing interests}

The authors declare that they have no competing interests.

Received: 4 May 2011 Accepted: 20 June 2011 Published: 20 June 2011

\section{References}

1. Shanmugasundaram P, Venkataraman S: Hepatoprotective and antioxidant effects of Hygrophila auriculata (K. Schum) Heine acanthaceae root extract. J Ethnopharmacol 2006, 104:124-128.

2. Valko M, Leibfritz D, Moncol J, Cronin MT, Mazur M, Telser J: Free radicals and antioxidants in normal physiological functions and human disease. Int J Biochem Cell Biol 2007, 39:44-84.

3. Bhadauria M, Nirala SK, Shukla S: Multiple treatment of propolis extract ameliorates carbon tetrachloride induced liver injury in rats. Food Chem Toxicol 2008, 46:2703-2712.

4. Hyogo H, Yamagishi S: Advanced glycation end products (AGEs) and their involvement in liver disease. Curr Pharm Des 2008, 14:969-972.

5. Fialova L, Malbohan I, Kalousova M, Soukupova J, Krofta L, Stipek S, Zima T: Oxidative stress and inflammation in pregnancy. Scand J Clin Lab Invest 2006, 66:121-127.

6. Zuwała-Jagiełło J, Pazgan-Simon M, Krzysztof Simon K, Maria Warwas M: Advanced oxidation protein products and inflammatory markers in liver cirrhosis: a comparison between alcohol-related and HCV-related cirrhosis. Acta Biochimica Polonica 2011, 58:59-65.

7. Kanter M, Coskun O, Budancamanak M: Hepatoprotective effects of Nigella sativa L. and Urtica dioica L. on lipid peroxidation, antioxidant enzyme systems and liver enzymes in carbon tetrachloride-treated rats. World J Gastroenterol 2005, 11:6684-6688.

8. Nevin KG, Vijayamma L: Effect of Aerva lanata against hepatotoxicity of carbon tetrachloride in rats. Environ Toxicol Pharmacol 2005, 20:471-477.

9. Halliwell B, Chirico S: Lipid peroxidation: its mechanism, measurement and significance. Am J Clin Nut 1993, 57:715-725.

10. Mitra SK, Venkataranganna MV, Sundaram R, Gopumadhavan S: Effect of HD-03, a herbal formulation, on the antioxidant defense system in rats. Phytother Res 1998, 12:114-117.

11. Bartley J, Jacobs A: Effects of drying on flavour compounds in Australiangrown ginger (Zingiber officinale). J Sci Food Agric 2000, 80:209-215.

12. Stoilova I, Krastanov A, Stoyanova A, Denev P, Gargova S: Antioxidant activity of a ginger extract (Zingiber officinale). Food Chem 2007, 102:764-770.

13. Shati AA, Elsaid FG: Effects of water extracts of thyme (Thymus vulgaris) and ginger (Zingiber officinale Roscoe) on alcohol abuse. Food Chem Toxicol 2009, 47:1945-9. 
14. El-Sharaky AS, Newairy AA, Newairy AA, Kamel MA, Eweda SM: Protective effect of ginger extract against bromobenzene-induced hepatotoxicity in male rats. Food Chem Toxicol 2009, 47:1584-1590.

15. Matsuda A, Wang Z, Takahashi S, Tokuda T, Miura N, Hasegawa J: Upregulation of mRNA of retinoid binding protein and fatty acid binding protein by cholesterol enriched-diet and effect of ginger on lipid metabolism. Life Sci 2009, 84:903-907.

16. Habib SH, Makpol S, Abdul Hamid NA, Das S, Ngah WZ, Yusof YA: Ginger extract (Zingiber officinale) has anti-cancer and anti-inflammatory effects on ethionine-induced hepatoma rats. Clinics (Sao Paulo) 2008, 63:807-813.

17. Bloch A, Thomson CA: Position of the American Diabetic Association: phytochemicals and functional foods. J Am Diet and Assoc 1995, 95:406-493.

18. Langner E, Greifenberg S, Gruenwald J: Ginger: history and use. Adv Ther 1998, 15:25-30

19. Sharififar F, Moshafi MH, Dehghan-Nudehe G, Ameri A, Alishahi F, Pourhemati A: Bioassay screening of the essential oil and various extracts from 4 spices medicinal plants. Pak J Pharmcol Sci 2009, 22:317-322.

20. Nadal NG: Sterols of Spirulina maxima. Phytochemistry 1971, 10:2537-2538

21. Seikel MK: Chromatographic methods of separation, isolation and identification of flavonoid compounds. The Chemistry of Flavonoid Compounds Macmillan Co, New York; 1962, 34.

22. Trease GEM, Evans WC: Trease and Evans pharmacognosy. 13 edition. Baillière Tindall, London; 1989

23. Marsillach J, Camps J, Ferré N, Beltran R, Rul A, Mackness B, Michael MM, Joven J: Paraoxonase-1 is related to inflammation, fibrosis and PPAR delta in experimental liver disease. BMC Gastroenterol 2009, 9:3.

24. Yuvaraj P, Subramoniam A: Hepatoprotective property of Thespesia populnea against carbon tetrachloride induced liver damage in rats. $J$ Basic Clin Physiol Pharmacol 2009, 20:169-177.

25. Buege JA, Aust SD: Microsomal lipid peroxidation. Meth Enzymol 1978, 52:302-310.

26. Moron MS, Depierre JW, Mannervik B: Level of glutathione, glutathione reductase and glutathone-S-transferase activities in rat lung and liver. Biochimica Biophysica Acta 1979, 582:67-78.

27. Nishikimi M, Rae NA, Yagi K: The occurrence of superoxide anion in the action of reduced phenazine methosulphate and molecular oxygen. Biochem Biophys Res Commun 1972, 46:849-853.

28. Rice ME, Shelton E: Comparison of the reduction of two tetrazolium salts with succinoxidase activity of tissue homogenates. J Nat Cancer Inst 1957 18:117-125.

29. Babson AL, Babson SR: Kinetic colorimetric measurement of serum lactate dehydrogenase activity. Clin Chem 1973, 19:766-769.

30. Swanson MA: Glucose-6-phosphatase from liver. In Methods in Enzymology. Volume 2. Academic press, NY; 1955:541-543.

31. Wattiaux R, De Duve C: Release of bound hydrolase by means of Triton X-100. Biochem J 1956, 63:606-608.

32. Bodansiky O, Schwartz MK: Comparative effects of L-histidine on the activities of 5-nucleotidase and alkaline phosphatase. J Biol Chem 1963, 238:3420-3427

33. Gella FJ, Olivella T, Cruz PM, Arenas J, Moreno R, Durban R, Gomez JA: A simple procedure for routine determination of aspartate aminotransferase and alanine aminotransferase with pyridoxal phosphate. Clin Chem Acta 1985, 153:241-247.

34. Bradford MM: A rapid and sensitive method for the quantitation of microgram quantities of protein utilizing the principle of protein-dye binding. Anal Biochem 1976, 72:248-254.

35. Rosalki SB, Foo AY, Burlina A: Multicenter evaluation of iso-ALP test kit for measurement of bone alkaline phosphatase activity in serum and plasma. Clin Chem 1993, 39:648-652.

36. Szasz G: A kinetic photometric method for serum y-glutamyl transpeptidase. Clin Chem 1969, 15:124-136.

37. Doumas BT, Perry BW, Sasse EA, Straumfjord JV: Standardization in bilirubin assays: evaluation of selected methods and stability of bilirubin solutions. Clin Chem 1973, 19:984-993.

38. Suzuki H, Suzuki K: Rat hypoplastic kidney ( $h p k / h p k$ ) induces renal anemia, hyperparathyroidism, and osteodystrophy at the end stage of renal failure. J Vet Med Sci 1998, 60:1051-1058.

39. Asad M, Shewade DG, Koumaravelou K, Abraham BK, Vasu S, Ramaswamy S: Effect of centrally administered oxytocin on gastric and duodenal ulcers in rats. Acta Pharmacol Sinica 2001, 22:488-92.
40. Opoku AR, Ndlovu IM, Terblanche SE, Hutchings AH: vivo hepatoprotective effects of Rhoicissus tridentata subsp. cuneifolia, a traditional Zulu medicinal plant, against $\mathrm{CCl} 4$-induced acute liver injury in rats. South African J Botany 2007, 73:372-377.

41. Anosike CA, Obidoa O, Ezeanyika LU, Nwuba MM: Anti-inflammatory and anti-ulcerogenic activity of the ethanol extract of ginger (Zingiber officinale). Af J Biochem Res 2009, 3:379-384.

42. Gowri Shankar GNL, Manavalan R, Venkappayya D, Raj CD: Hepatoprotective and antioxidant effects of Commiphora berryi (Arn) Engl bark extract against $\mathrm{CCl} 4$-induced oxidative damage in rats. Food Chem Toxicol 2008, 46:3182-3185.

43. Manna P, Sinha M, Sil PC: Aqueous extract of Terminalia arjuna prevents carbon tetrachloride induced hepatic and renal disorders. BMC Comp Alt Med 2006, 6:33.

44. Mansour HH, Hafez HF, Fahmy NM: Silymarin modulates cisplatin-induced oxidative stress and hepatotoxicity in rats. J Biochem Mol Biol 2006, 39:656-661.

45. Yadav NP, Pal A, Shanker K, Bawankule DU, Gupta AK, Darokar MP, Khanuja SPS: Synergistic effect of silymarin and standardized extract of Phyllanthus amarus against CCl4-induced hepatotoxicityin Rattus norvegicus. Phytomedicine 2008, 15:1053-1061.

46. Romero FJ, Bosch-Morell F, Romero MJ, Jareno EJ, Romero B, Marín N Romá J: Lipid peroxidation products and antioxidants in human disease. Environ Health Perspectives 1998, 106:1229-1234.

47. Sharma N, Shukla S: Hepatoprotective potential of aqueous extract of Butea monosperma against $\mathrm{CCl}_{4}$ induced damage in rats. Exp Toxicol Pathol 2010.

48. Reyes-Gordillo K, Segovia J, Shibayama M, Vergara P, Moreno MG, Muriel P: Curcumin protects against acute liver damage in the rat by inhibiting NF-kappa B, proinflammatory cytokines production and oxidative stress. Biochem Biophys Acta 2007, 1770:989-996.

49. Leonard TB, Neptun DA, Popp JA: Serum gamma glutamyl transferase as a specific indicator of bile duct lesions in the rat liver. Am J Pathol 1984 116:262-269.

50. Hamed MA: Metabolic profile of rats after one hour of intoxication with a single oral dose of ethanol. J Pharmacol Toxicol 2011, 6:158-165.

51. Ohyashiki T, Kamata K, Takeuchi M, Matsui K: Contribution of peroxidation products to oxidative inactivation of rat liver microsomal glucose-6phosphatase. J Biochem 1995, 118:508-514.

52. Nkosi CZ, Opoku AR, Terblanche SE: Anti-oxidative effects of pumpkin seed (Cucurbita pepo) protein isolate in CCl4-induced liver injury in lowprotein fed rats. Phytother Res 2006, 20:935-940.

53. Kumaravelu P, Dakshinamoorthy DP, Subramaniam S, Devarajt $H_{4}$ Devaraj NS: Effect of eugenol on drug-metabolizing enzymes of carbon tetrachloride-intoxicated rat liver. Biochem Pharmacol 1995, 49:1703-1707.

54. Rusu MA, Tamas M, Puica C, Roman I, Sabadas M: The hepatoprotective action of ten herbal extracts in CCl4 intoxicated liver. Phytother Res 2005, 19:744-749.

55. Jewell SA, Bellomo G, Thor H, Orrenius S, Smith MT: Bleb formation in hepatocytes during drug metabolim is caused by disturbances in thiol and calcium ion homeostasis. Science 1982, 217:1257-1259.

56. Jadon A, Bhadauria M, Shukla S: Protective effect of Terminalia belerica Roxb. and gallic acid against carbon tetrachloride induced damage in albino rats. J Ethnopharmacol 2007, 109:214-8.

57. De-Andrade Belo MA, Soaresa VE, de Souza LM, Sobreira MFR, Cassol DMS, Toma SB: Hepatoprotective treatment attenuates oxidative damages induced by carbon tetrachloride in rats. Exp Toxicol Pathol 2010.

58. Kataria M, Singh LN: Hepatoprotective effect of liv.52 and kumaryasava on varbon tetrachloride induced hepatic damage in rats. Indian J Exp Biol 1997, 35:655-657

59. Achliya GS, Kotagale NR, Wadodkar SG, Dorle AK: Hepatoprotective activity of Panchagavya ghrita against carbon tetrachloride induced hepatotoxicity in rats. Indian J Pharmacol 2003, 35:308-311.

60. Banu GS, Kumar G, Murugesan AG: Ethanolic leaves extract of Trianthema portulacastrum I. ameliorates aflatoxin b1 induced hepatic damage in rats. Indian J Clin Biochem 2009, 24:250-256.

61. Tsukada S, Parsons CJ, Rippe RA: Invited critical review.Mechanisms of liver fibrosis. Clin Chem Acta 2006, 364:33-60.

62. Li GS, Jiang WL, Tian JW, Qub GW, Zhu HB, Fu FH: In vitro and in vivo antifibrotic effects of rosmarinic acid on experimental liver fibrosis. Phytomedicine 2010, 17:282-288 
doi:10.1186/1743-7075-8-40

Cite this article as: Motawi et al: Zingiber officinale acts as a

nutraceutical agent against liver fibrosis. Nutrition \& Metabolism 2011

8:40.

Submit your next manuscript to BioMed Central and take full advantage of:

- Convenient online submission

- Thorough peer review

- No space constraints or color figure charges

- Immediate publication on acceptance

- Inclusion in PubMed, CAS, Scopus and Google Scholar

- Research which is freely available for redistribution 